\title{
Investigation of Blank Cartridge Gun Harming Potential in Target Range of 0-5 cm
}

\section{Kuru S1k1 Silahların Hedefe 0-5 cm Mesafeden Yaralama Potansiyelinin İncelenmesi}

\author{
Serbülent Kılıç ${ }^{1}$, Gürol Cantürk ${ }^{2}$, Gökhan İbrahim Öğ̈̈nç ${ }^{3}$ \\ ${ }^{1}$ Department of Forensic Medicine, Bursa Yuksek Ihtisas Training and Research Hospital, Bursa \\ ${ }^{2}$ Department of Forensic Medicine, Ankara University Medical School, Ankara \\ ${ }^{3}$ Criminal Department of General Directorate of Security, Ankara
}

\begin{abstract}
Objective: The aim of our study is to show through experiments harming potential of blank firing guns, which are known to be harmless mistakenly.

Materials and Methods: Two different types of blank firing guns were utilized to shot at chicken leg as a tissue simulant; at a distance of $0-5 \mathrm{~cm}$. Results of the experiments were photographed and recorded in a digital platform.

Contact shot at chicken leg caused full-thickness bone fracture and full-thickness tissue penetration. In contrast, correlation was not detected between dimensions of smoothing and tissue damage on the target. We think that the causes of results that have no correlation, as weather conditions, wind, temperature, defiency of blank cartridge guns.

Results and Conclusion: The results we had, studies and case reports about this subject in literature exhibit obviously harming potential of blank firing guns for human body. No significant correlation was determined between damage, diameter of soot and shot range in $0,1,2$, 3,4 and $5 \mathrm{~cm}$. A new research about the correlation between damage, diameter of soot and different close range of shot can be performed in another study.

Keywords: Firearm; Gun Powder; Contact Shot; Bone Fracture;
\end{abstract} Blank Cartridge Gun Injuries; Handgun.

\section{Özet}

Amaç: Çalışmamızın amacı; toplumda zararsız olarak bilinen kuru sıkı silahların organik bir hedefe yapılan atışlar ile meydana getirebileceği yaralanma potansiyelinin deneysel olarak gösterilmesidir.

Gereç ve Yöntem: Doku simulantı olarak tavuk eti but bölümü hedef olarak belirlenmiş ve iki farklı yapıda kuru sıkı tabanca ile 0-5 $\mathrm{cm}$ mesafeden atışlar yapılmıştır. Bulgular ölçülerek, fotoğraflanmış ve dijital ortamda kayıt edilmişsir.

Kuru sıkı tabanca ile tavuk etine yapılan bitişik atış sonucu tam kat doku penetrasyonu ve kemik dokusunda tam kat kırık saptanmıştır. Ancak hedefte, atış mesafesi ile oluşan isin çapı ve doku hasarı ölçümleri bakımından korelasyon tespit edilememiştir. Elde ettiğimiz sonuçlarda anlamlı korelasyon olmamasında; hava koşulları, rüzgâr, ortam sıcaklığı, kuru sıkı tabancaların konvansiyonel silahlar kadar verimli düzeneklerinin olmaması gibi sebeplerin etkili olabileceğini düşünmekteyiz.

Bulgular ve Sonuç: Elde ettiğimiz sonuçlar ve konu ile ilgili literatürdeki çalıșmalar, kuru sıkı silahların insan bedeninde yaralanmalara sebep olabileceğini açıkça ortaya koymaktadır. $0,1,2,3,4$ ve $5 \mathrm{~cm}$ atış mesafesi ile hasar ve is çapı arasında anlamlı korelasyon tespit edilmedi. Başka bir bilimsel çalıșmada, farklı yakın atış mesafeleri ile hasar ve is çapı arasında korelasyon olup olmadığı değerlendirilebilir.

Anahtar Kelimeler: Ateşli Silah; Barut; Bitişik Atış; Kemik Kırı$\breve{g} 1$; Kuru Sıkı Silah Yaralanmaları; Tabanca.

\section{Introduction}

The term of firearm refers to a system which can send an object to a long distance by the pressure of gun powder. In contrast, blank cartridge gun, a type of firearm, is designed for not to shot away a solid object. Although blank guns cannot project a solid object, we found out that these guns could cause mortality in our study.

In Turkish Law, production and sale of blank cartridge guns are subject to No. 5729 Audio \& Gas Cartridge be-

Corresponding Author: Uzm. Dr. Serbülent Kılıç

Bursa Yüksek Ihtisas Training and Research Hospital, Department of Forensic Medicine, Bursa

Email:kilicserbulentmd@gmail.com

Gelişs: 25.11.2016 Düzeltme: 25.07.2017 Kabul: 15.09.2017 ing capable of riding on Weapons Laws and Regulations. In the first paragraph of first passage's fifth article that regulates the production basis, it is suggested that "a pin of barrel for safety which made up of steel "should be placed. The pin length must be half of barrel length at least. The pin must be located in the middle of barrel."

"Barrel safety sheet" which is in the barrel of a blank gun; should be at least half of the barrel length, except the cartridge chamber length, and should be made of steel. The blank gun must contain also 'barrel safety pin' which is put between the muzzle and the barrel and "barrel safety sheet". 'Barrel safety pin' should be made of steel and should be positioned perpendicularly to the large surfaces of the sheet. Part of the "Barrel safety sheet" can be pro- 
duced not to be in the same axis by having at least 1.5 $\mathrm{mm}$ misalignment, instead of the safety pin. Safety sheet cartridge should be in the mattress side. The sheet and pin must be placed in a way that cannot be removed easily into the barrel.

In 2nd. paragraph: "steel barrel of safety" should be placed into the barrel made of hardened steel to completely close the diameter of the barrel. The steels should have the geometric shape to prevent puncture of the barrel. The steels should also be placed in the barrel, and should prevent from being removed in an unfavorable way. Barrel safety steels should be positioned at the nearest end of the breech. In this study, the harming potential of two different types of blank firing guns, which were produced according to 5729 No Turkish Law, were examined experimentally and analyzed statistically.

Blank gun injury patterns are different from real firearm injury patterns. In this condition, this type of injury can be ignored. So, it cannot be included in the criminal record of this type of injuries. Aim of study is to increase the awareness of the blank cartridge guns which can shot away blank or tear gas cartridge.

\section{Materials and Methods}

In our study two different types of $9 \mathrm{~mm}$ blank guns which could discharge blank cartridges were used. The guns we used are in accordance with No. 5729 Audio \& Gas Cartridge Weapons Laws and Regulations.
The first type of gun had a 'circle restraint piece' in the barrel. The circle restraint piece had a hole in the middle. The gun could discharge tear gas cartridge or blank ammunition. When the trigger was pulled, the pressure developed. The pressure was discharged through the hole of circle restraint piece.

The second type of gun had a 'vertical restraint piece' in barrel. The vertical restraint piece was found out along the barrel. The vertical restraint piece divided the barrel into two equal parts. This gun could also discharge tear gas cartridge and blank ammunition. When the trigger was pulled, the pressure developed. The pressure was discharged out around the vertical restraint piece.

The intended purpose of restraint piece is to prevent to discharge a solid object out of the muzzle. The restraint pieces, which were used in our study, had all the necessary qualities for this aim. These guns are designed to discharge tear and blank ammunition.

Turaç Victory Sport ${ }^{\circledR}$ brand blank cartridges, which could develop 400-425 bar pressure, were used in our study. Blank firing guns were utilized to shot at chicken leg as a tissue simulant; at a distance of $0-5 \mathrm{~cm}$ at right angles. The chickens, which were sacrificed at the 50th day of their lives, were bought from the butcher. After performing of shootings, the destructions which occurred were evaluated by ruler and compass. The destruction areas were photographed and shown in Figure 1.a-c and 2.a-c).

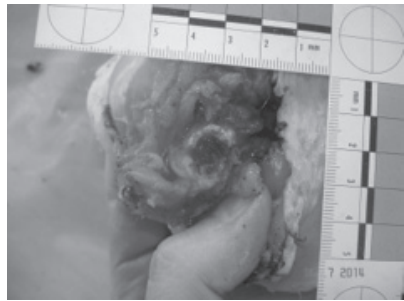

$1-\mathrm{a}$

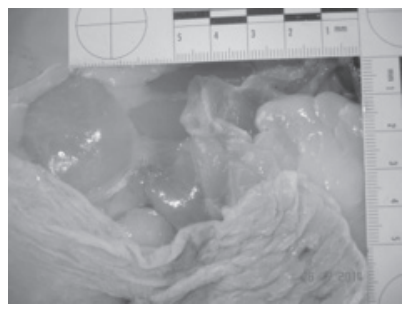

2-a

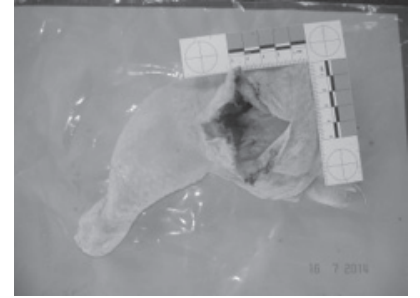

$1-b$

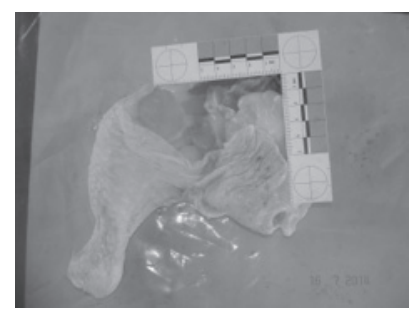

$2-b$

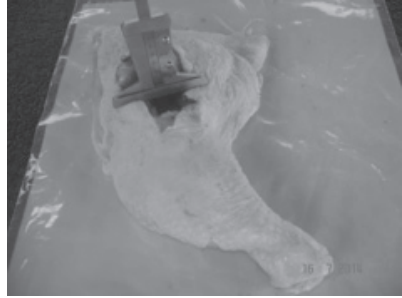

1-c

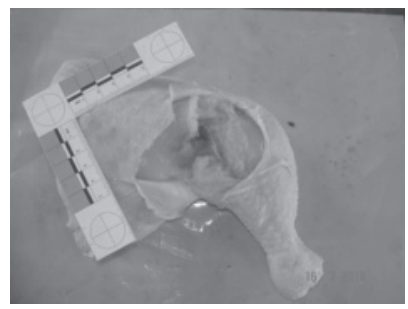

2-c

Figure 1.a-b-c, 2.a-b-c

Upper side: Picture in the left: 1a, Picture in the Middle: $1 \mathrm{~b}$, Picture in the right: $1 \mathrm{c}$

Lower side: Picture in the left: $2 \mathrm{a}$, Picture in the Middle: $2 \mathrm{~b}$, Picture in the right: $2 \mathrm{c}$ 
At the end of the study, relationships of correlation were evaluated statistically between destructions that occurred on skin, in muscle tissue and in bone tissue, penetration depth of shots, diameter of soot on skin and the range of shots. IBM SPSS Statistics Version 20 program was used for the statistical analysis.

The analysis of spearman correlation and regression were performed. $\mathrm{P}<0,01$ and 0,05 values are allowed.

The approval for the study was obtained from the ethics committee of Medical Faculty of Ankara University.

\section{Results}

\subsection{The Examination of Destruction that Occurred on Target Tissue}

In the study of 1st type of blank gun shots, analysis of correlation was performed between variables of 'range of shot' and 'diameter of destruction area on skin tissue'. But it was not correlated $(\mathrm{p}=0.518>0.05)$. The spearman coefficient was $-0,086$. In the study of 2 nd type of blank gun shots, analysis of correlation was performed between variables of 'range of shot' and 'diameter of destruction area on skin tissue'. But it was not correlated, too $(p=0.872>0.05)$. The spearman coefficient was $-0,086$.

\subsection{The Examination of Diameter of Soot that Occurred on Target Tissue}

In the study of 1st type of blank gun shots, analysis of correlation was performed between variables of 'range of shot' and 'diameter of soot on target tissue'. It was correlated $(p=0,021<0.05)$. The spearman coefficient was $-0,880$. Then, analysis of regression was performed between variables of 'range of shot' and 'diameter of soot on target tissue'. The regression was found not linear $(p=0,098>0,05)$. In the study of 2 nd type of blank gun shots, analysis of correlation was performed between variables of 'range of shot' and 'diameter of soot on target tissue'. But it was not correlated $(p=0,913>0.05)$. The spearman coefficient was $-0,058$.

\section{Discussion}

Injury of blank cartridge gun is a significant subject that is getting bigger day by day. All the physicians can meet with the patients or victims who get injured by being exposed to blank guns, forensic medicine specialists as well.

Although these weapons are believed as harmless in society, many studies were performed about damage to the human body with these guns. In the literature, the cases were caused from blank gun injuries were reviewed. Fracture of the occipital bone, injuries of the lung, heart, diaphragm, spleen capsule, small bowel, vena cava infe- rior and abdominal aort (1), lung contusion (2), jejunal perforation, greater omentum hematoma (3), jugular vein damage (4), squamous part of temporal bone fracture, epidural hematoma, contusion in the temporal lobe (5), damages of the liver, stomach, colon, rectum, pancreas, tissue loss in the abdominal lateral wall, injuries of the small intestine and colon mesentery (6), diffuse cerebral edema, parietal bone fracture, intracranial hematoma, brain parenchyma laceration through right and left temporal lobes, subarachnoid hemorrhage in the brain (7) were reported before.

In the first experiment of our study; two different types of blank firing guns were utilized to shot at chicken leg as a tissue simulant; at a distance of $0-5 \mathrm{~cm}$. The shootings were performed at six different distances from the chicken. The analysis of correlation was performed between variables of 'range of shot as centimeter' and 'diameter of destruction area on skin tissue as millimeter'. But no correlation was found. However, the statistical results of both guns showed that there was no significant correlation between the range of shot and diameter of destruction area on skin tissue.

In the second experiment of our study; two different types of blank firing guns were utilized to shot at chicken leg as a tissue simulant; at a distance of $0-5 \mathrm{~cm}$. The shootings were performed at six different distances from the chicken. The analysis of correlation was performed between variables of 'range of shot as centimeter' and 'diameter of soot on target tissue as millimeter'. But no correlation was found, either. However, the statistical results of both guns, showed that there was no significant correlation between the range of shot and diameter of soot on target tissue.

As a conclusion, we have determined no significant correlation. Some reasons as weather conditions, flow of wind, temperature may be effective fallaciously during the shootings. On the other hand, blank guns do not have efficient mechanisms as conventional weapons. This can affect illusively, too. We believe that it would be beneficial to perform more studies on this subject.

The first type of gun shooting in close range caused full thickness of tissue penetration, full thickness of bone fracture (Figure. 1a). However, the second type of gun shooting in close range in two times caused no bone fracture. In the literature, many of publications about blank gun injuries revealed that blank guns could be harmful for the soft tissue and the bone tissue. Our findings were consistent with the literature (1, 7-22). In present study, blank guns caused skin tissue damage, destruction of muscle tissue, burnings and the soot, frequently. It was revealed that how blank guns could be harmful. 
In general, shootings of the second type have been shown to cause less damage. Only the first type of blank gun caused bone fractures in close range. We think that this must be considered while legislating about these guns. Manufacturing of these guns needs more strict norms.

Bruises, lacerations, burns can be seen in blank gun injuries. Forensic medicine specialists and emergency service physicians should examine atypical injury cases carefully and beware of undiagnosed cases. If the objects inserted in the blank gun cartridges are not metallic structure, they could not be detected by radiography or scopy device (23).

In a study, five guns having different brands were examined at the point of ballistics suggested that; all weapons caused ballistic traces on the cartridge case by the shootings. The cartridges did not lose this specification during the shootings and the traces showed no significant differences in the capsule (24). In ballistic view, the evaluation of blank guns is getting harder due to modifications of the blank guns.

Frequent usage of these types of weapons in criminal cases reminds that legislation is not adequate. In Europe, legislations of producing and licensing of blank guns are arranged to prevent projecting bullets from the muzzle and transferring of big amounts of energy (25).

In German speaking countries, laws about weapons are quite strict and new models of blank guns are tested by a technical examination in federal institutes of physics and technology (26). If kinetic energy of blank gun shooting exceeds $7.5 \mathrm{~J}$ or blank gun does not meet all the conditions, it is not allowed to be sold in the market (26). Manufacture, transportation and sales of blank guns must be regulated with more strict laws and usage of these guns must be controlled more frequently for the sake of public health.

Education of people about potential of blank cartridge gun injuries and designing these guns to prevent to project gas pressure out of the muzzle have a significant importance (5). According to legislations about blank guns in some European countries, blank gun sellers and customers must be informed about the dangers of these weapons (27). In German laws, it is sufficient to have only an identity card while buying one (13). Some countries in Europe, alarming guns, blank cartridge guns and other non-lethal weapons are permitted to adults aged 18 and older (27).

Reducing the harming potential by some limitations is possible while producing. If the gas pressure is reduced, harming capacity of blank guns will be decreased, too. Although blank guns cannot projectile a cartridge, these guns are still used in criminal cases (27). While designing blank guns, the main aim is to produce loud voice. Burning and developing of gas pressure should be prevented. It is considered that if blank guns are produced in these conditions, the number of injuries and deaths will reduce.

Prevention of blank gun modifications will make these guns more harmless. In a study; the prevention of the blank gun cartridge modifications has two important elements (28). The first one is; getting blank cartridge case shorter. Thus, cartridge case will be lower capacity to involve steel or lead beads. Steel or lead beads are put at the top of the cartridge case to increase harming potential. The second one is; gathering of cartridge case crimp like in blank cartridge case which is used in blank revolvers (28).

In conclusion, our study revealed the harming potential of blank cartridge guns for the human body. The limits of the laws and regulations about blank guns were underlined. We believe that, accessibility of blank cartridge guns should not be easy. Educating sellers and customers of these guns is of vital importance. It should not be ignored that blank cartridge guns can cause mortality like all firearms.

\section{References}

1. Arslan MM, Karanfil R, Akcan R et al. A growing danger: Blank cartilage guns. Bull Leg Med 2007;12(1):21-4. doi: http://dx.doi.org/10.17986/blm.2007121628

2. Akdur O, Ozdemir C, Ozkan S et al. Lung contusion due to blank cartridge bullet expulsive explosion: Case report. JAEM 2010; 9(1):56-8. doi: 10.4170/JAEM.2009.50479

3. Teke Z, Atalay AO, Tekin K. Penetrating abdominal wound caused by a close-distance blank cartridge pistol shot: a case report. TJTES 2009;15:191-3.

4. Ikizceli I, Avşaroğulları L, Sözüer EM et al. Juguler vein gunshot injury from blank cartridges. TJTES 2005;11:254-7.

5. Demirci Ş, Doğan KH, Erkol Z et al. A suicidal death case with an unmodified blank cartridge gun. Bull Leg Med 2008;13(1):25-9. doi: http://dx.doi.org/10.17986/ blm.2008131669

6. Korkmaz O, Yılmaz H, Taçyıldız I. Abdominal trauma due to blank cartridge guns. Turk J Emerg Med 2006;6(2):66-8.

7. Tokdemir M, Türkoğlu A, Kafadar H. Three death cases occurred by blank cartrİdge guns: Case report. Bull Leg Med 2011;16(2):60-3. doi: http://dx.doi.org/10.17986/ blm.2011162727

8. Zdravkovic M, Milic M, Stojanovic M, et al. Three cases of death caused by shots from blank cartridge. Am J Forensic Med Pathol 2009;30(4):403-6. doi: 10.1097/ PAF.0b013e3181c15d8c.

9. Gülşen I, Ak H, Sosuncu E, Bulut MD. Are blank cartridge guns really harmless? Ulus Travma Acil Cerrahi Derg 
2014;20(3):214-6. doi: 10.5505/tjtes.2014.90868.

10. Buyuk Y, Cagdir S, Avsar A et al. Fatal cranial shot by blank cartridge gun: two suicide cases. J Forensic Leg Med 2009;16(6):354-6. doi: 10.1016/j.jflm.2009.01.011.

11. Uzün I, Büyük Y, Erkol Z et al. Fatalities caused by spherical bullets fired from blank cartridge guns in Istanbul, Turkey. J Forensic Sci 2009;54(5):1127-30. doi: 10.1111/ j.1556-4029.2009.01097

12. Ozdes T, Boz H, Yazici YA, Kumral B. Death due to gas pressure of blank firing gun: a case report. J For Med 2014;28(1):85-90 doi:10.5505/adlitip.2014.36025

13. Rothschild MA, Karger B, Strauch H, et al. Fatal wounds to the thorax caused by gunshots from blank cartridges. Int J Legal Med 1998;111(2):78-81.

14. Di Maio VJM. Gunshot Wounds. 2nd edition, CRC Press, New York, 1999: 321-4.

15. Perdekamp MG, Glardon M, Kneubuehl BP et al. Fatal contact shot to the chest caused by the gas jet from a muzzleloading pistol discharging only black powder and no bullet: case study and experimental simulation of the wounding effect. Int J Legal Med 2015;129(1):125-31. doi: 10.1007/ s00414-014-1064-3.

16. Arısoy Y. Biological residues on bullets. J For Med 2010;24(2):16-21.

17. Aslan S, Uzkeser M, Katirci Y et al. Air guns: toys or weapons? Am J Forensic Med Pathol 2006;27(3):260-2. doi:10.1097/01.paf.0000220919.45493.af

18. Özdeş T, Erkol Z, Cantürk N, Koçak U, Tekelioğlu ÜY. A Case of Accidental Child Death Which Occurred with Blank Cartridge Gun [Kurusıkı Tabanca ile Oluşan Kaza Orijinli Çocuk Ölümü Olgusu]. Medicine Science. 2014;3(2):128998 doi: 10.5455/medscience.2013.02.8116
19. Perdekamp MG, Schmidt U, Rupp W et al. Contact shot with unusual soot pattern. Forensic Sci Int 2005;20;149(1):75-9. doi:10.1016/j.forsciint.2004.06.035

20. Uzar AI, Dakak M, Oner K et al. Comparison of soft tissue and bone injuries caused by handgun or rifle bullets: an experimental study. Acta Orthop Traumatol Turc 2003;37:261-7.

21. Uzar A, Dakak M, Ozer T, et al. A new ballistic simulant" transparent gel candle" (experimental study). TJTES 2003;9:104-6.

22. Ozer M, Ogunc G, Eryilmaz M et al. Organ models in wound balistics: experimental study. TJTES 2007;13:20.

23. Cantürk N, Işbaşar T, Erdönmez F, Teke HY. Kuru sıkı silah fişeğine yabancı cisim yerleştirilmesi ile cinayet-olgu sunumu. 5. Anadolu Adli Bilimler Kongresi Bildiri Özet Kitabı. 2006:58

24. Sarıbey AY, Hannam AG, Tarımcı Ç. An investigation into whether or not the class and individual characteristics of five Turkish manufactured pistols change during extensive firing. J Forensic Sci 2009;54(5):1068-72. doi: 10.1111/ j.1556-4029.2009.01107

25. Giese A, Koops E, Lohmann F, et al. Head injury by gunshots from blank cartridges. Surg Neurol 2002;57(4):268-77.

26. Rothschild M, Liesenfeld O. Is the exploding powder gas of the propellant from blank cartridges sterile? Forensic Sci Int 1996;11;83(1):1-13. doi: 10.1016/0379-0738(96)02019-1

27. Clarot F, Vaz E, Papin F, et al. Lethal head injury due to tear-gas cartridge gunshots. Forensic Sci Int 2003;137:4551. doi: 10.1016/S0379-0738(03)00282-2

28. Ogunc IO, Ozer MT, Coskun K, Uzar AI. Modified blank ammunition injuries. Forensic Sci Int 2009;15;193(13):112-7. doi: 10.1016/j.forsciint.2009.09.021 